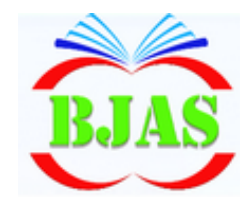

ISSN 1814 - 5868
Available online at http://bajas.edu.iq

https://doi.org/10.37077/25200860.2019.206

College of Agriculture, University of Basrah

Basrah J. Agric. Sci., 32(2) 160-168, 2019

\section{Basrah Journal of Agricultural Sciences}

E-ISSN: 2520-0860

\title{
Field Efficacy of Pesticides Against Dust Mites Oligonychus afrasiaticus (McGregor) (Acari: Tetranchidae) on Date Palm, Hillawi Cultivar
}

\author{
Hazim M. Ali* \& Khalid A. Fhaid \\ ${ }^{1}$ Date Palm Research Centre, University of Basrah, Iraq \\ 2 Department of Plant Production, College of Agriculture, University of Basrah, Iraq \\ *Corresponding author E-mail: altemem2010@gmail.com \\ Received 19 September 2019; Accepted 18 November 2019; Available online 31 December 2019
}

\begin{abstract}
This study was carried out to evaluate some pesticides with two methods of control (preventative and curative) in a private field in the region of Abu AlKhaseeb in Basrah province during the growing season of 2018 / 2019; treatments were applied in three dates (eight weeks, ten weeks and twelve weeks) after the pollination of the date palm trees $(28 / 2 / 2019)$. The results recorded that the $1^{\text {st }}$ spray was the most effective in reducing the population density of the dust mites compared to the second and third spraying rate $(49.25,45.40$ and 42.69$) \%$ respectively. The dormant spray carried out in December 2018 that reduced the population density of the pest below the economic threshold by using Sulphur (200, 300 and 400) G/palm and Matrixine (1, 1.5 and 2) Ml.L $\mathrm{L}^{-1}$; the population density was decreased to 7.88 , 4.15 and 4.05 mites and to $7.53,4.31$ and 3.96 mites by controlling with Sulphur and Matrixine, respectively, compared to the untreated palms $(8.63,24.53$ and 42.40 mites) at the sampling events 15 March, 15 April and 15 May.
\end{abstract}

Keyword: Dormant spray, Matrixine Oil, Ortus, Levo, Oligonychus afrasiaticus, Sulfur.

\section{Introduction}

Phytophagous mites are a serious pest for many crops; all stages of mites infest different plant growth stages decreasing the production across worldwide; the damage results from the feeding of the mite stages on different vegetable and floral parts of plants $(\mathrm{Ba}$ Angood \& Basshaih, 2000). Dust mites Oligonychus afrasiaticus (McGregor) is one of the most serious pests of date palm. The larvae, nymphs, and adults feed on date fruits stages of Kimri and the Khalal by sucking the sap from the fruits; this mite infests different cultivars, and the most sensitive cultivars are Al-Burahi and Al-Halawi, followed by cultivar Al-Khadrawy and al-Diry which are the moderate sensitive cultivars, whereas the lowest sensitive cultivar are Al-Sayer and AlZahidi. The mites has chelicerae jaws inserted into the rind of the fruit, causing discoloration, and the dark fruit appears reddish, especially the area near the funnel (Al-Swuidy, 2003). Usually, the infested palms are been controlled by using different types of insecticides, but the broad-spectrum chemical pesticides eventually led to some problems such as an imbalance in the ecosystem (Al-Dahwi, 2008). Development of resistance to chemical pesticides and the disappearance of natural enemies such as predators and parasites. Applying the 
chemical pesticides at the proper time and using the natural pesticides have special characteristics as low toxicity to humans and animals and no damage to plants led to successful control (Robinson, 1996).

Dust mite caused economic losses by reducing productivity and the marketing value of date palm fruits. A few studies have conducted on this pest in Iraq, for that the present study aimed to evaluate the efficiency of four chemical pesticides to control this pest.

\section{Materials \& Methods}

\section{Acaricides}

\section{Studying the effectiveness of curative spray} on the dust mites at three spray application intervals

This experiment was conducted in a private orchard of date palm at Abu Al-Khaseeb region, Basrah province during the growing season of 2018/2019; twelve date palm trees were selected at the same ages as much as possible. The pesticides were applied (1,2 and 3. see table 1) at various time intervals; the first spraying time was conducted after four weeks of the pollination, the second and third times were after six and eight weeks respectively after the pollination of the trees; control treatment sprayed using water (AlDosary et al., 2013). Trees were sampled to calculate the population density of mites by collecting leaflets of palm leaves (new and old leaves); 100 fruits were taken randomly (25 fruits from each direction); the samples were put in the plastic bags and brought to the laboratory. O. afrasiaticus were counted by using a dissecting microscope (BEL photonics) with objective lens $(2 \mathrm{X}, 4 \mathrm{X})$. The equation of Henderson-Tilton's formula was used to evaluate the efficacy of the pesticides (modified methods of Al-Dosary et al., 2013).

Corrected efficacy $\% \quad=\left(1-\frac{\text { No. of mites in Co before spraying } * \text { No. in T after spraying }}{\text { No. in Co after spraying } * \text { No. in T before spraying }}\right) * 100$

Where: No. $=$ insect population, $\mathrm{T}=$ treatment, $\mathrm{Co}=$ control

Table (1): Pesticides were evaluated for control of dust mites Oligonychus afrasiaticus.

\begin{tabular}{cccc}
\hline N. & Acaricides & Chemical group & Recommended dosage \\
\hline 1 & ORTUS 5\% EC & Fenpyroximate & $1.5{\mathrm{~m} . \mathrm{l}^{-1}}^{-1}$ \\
\hline 2 & Matrixine Plus & Abamactein + oxymatrin & $1 \mathrm{~m} \mathrm{l}^{-1}$ \\
\hline 3 & Levo 2.4\% SL & Plant extract Oxymatrine & $1 \mathrm{~m} \mathrm{l}^{-1}$ \\
\hline 4 & Sulfur & Inorganic & $300 \mathrm{~g}$. date $^{-1}$ \\
\hline 5 & Matrixine Oil & $2.4 \%$ oxymatrine & $1.5{\mathrm{~m} . \mathrm{l}^{-1}}$
\end{tabular}


Ali \& Fhaid / Basrah J. Agric. Sci., 32 (2): 170-178, 2019

Studying the effectiveness of preventative spray on dust mites during the dormant season

This study was conducted on a private date palm orchard in Abu Al-Khaseeb region on December 2018; 21 trees were selected to conduct the experiment. The pesticides were applied( 4 and 5 from table 1 ) The top of the palm was dusted with sulfur $(200,300$, and 400) g.tree ${ }^{-1}$ by Duster Matabi-Bazooka Duster- $750 \mathrm{~g}$ ) and Matrixine (oil) with three dosages (1, 1.5, and 2) ml.litre ${ }^{-1}$ using a sprayer (the capacity of 16 litres). The control treatment was sprayed with water. Data of population density of the mites were recorded at $15 / 3$ and $15 / 4$ and $15 / 5 / 2019$ after the end of dormant season by collecting leaflets of palm leaves (new and old leaves). Also 100 fruits were sampled (25 fruits from each direction) and were put in the plastic bags and brought to the laboratory; the dust mites were counted by using a dissecting microscope
(BEL photonics ) with an objective lens (2X, 4X) (Hamarassh et al., 2006).

\section{Statistical Analysis}

Data were analyzed according to the complete randomized design and means were separated using Least Significant difference (L.S.D.) test at $\mathrm{p} \leq 0.05$. The analysis was conducted by using SPSS v. 21

\section{Results \& Discussion}

Effect of curative spray on the dust mites at three spray application intervals

Data in fig. (1) showed that the first spray recorded the highest effect by decreasing the population density of dust mite on date palm trees; the mortality percentage was $49.25 \%$, followed by the second and third spray (45.40 and 42.69) \% respectively. Ortus was the superior causing highest mortality of the dust mite which reached $69.63 \%$, followed by Matrixine Plus and Levo (59.68 and $49.22 \%$ respectively, fig. 2).

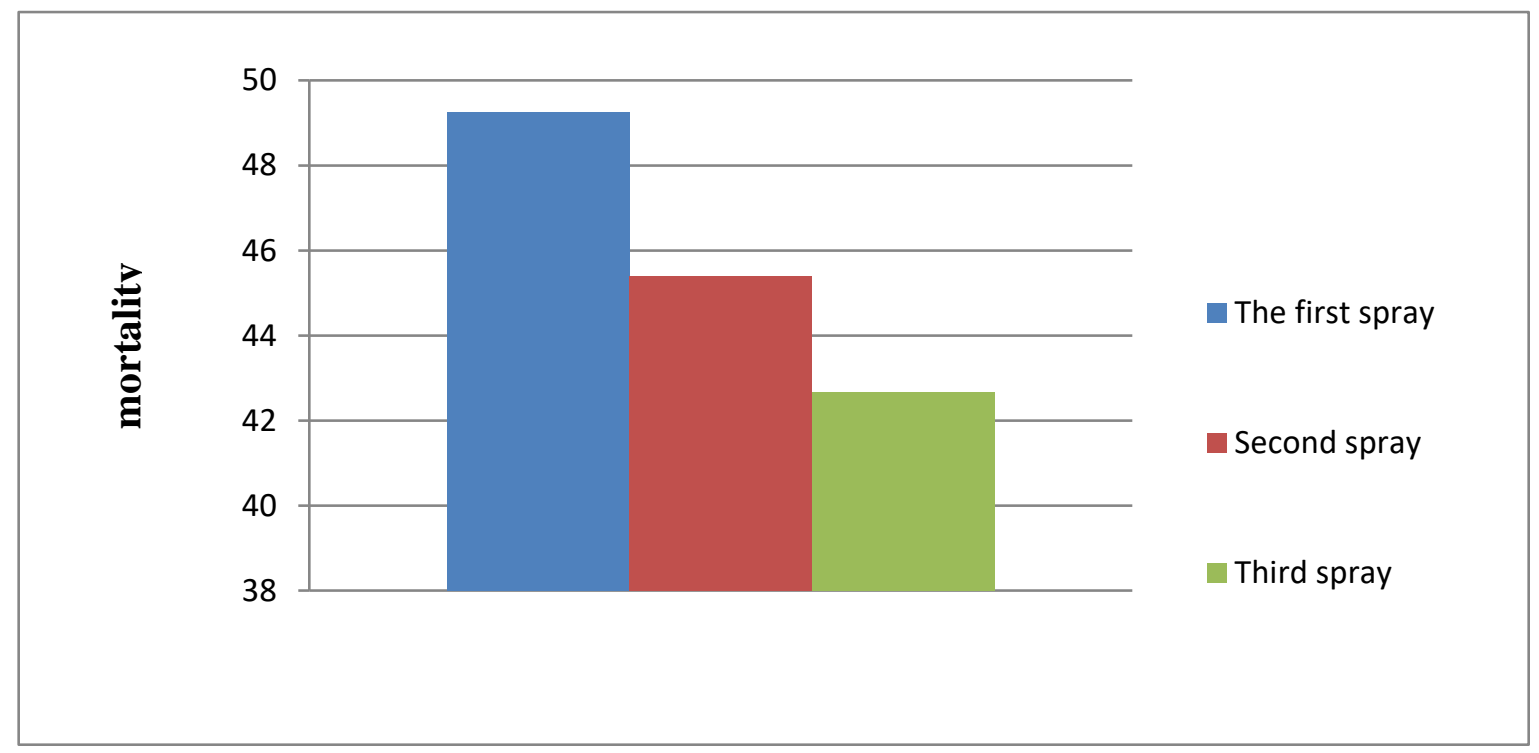

Fig. (1) Effect of the spray application intervals of pesticides on the mortality percentage of dust mites. 
Ali \& Fhaid / Basrah J. Agric. Sci., 32 (2): 170-178, 2019

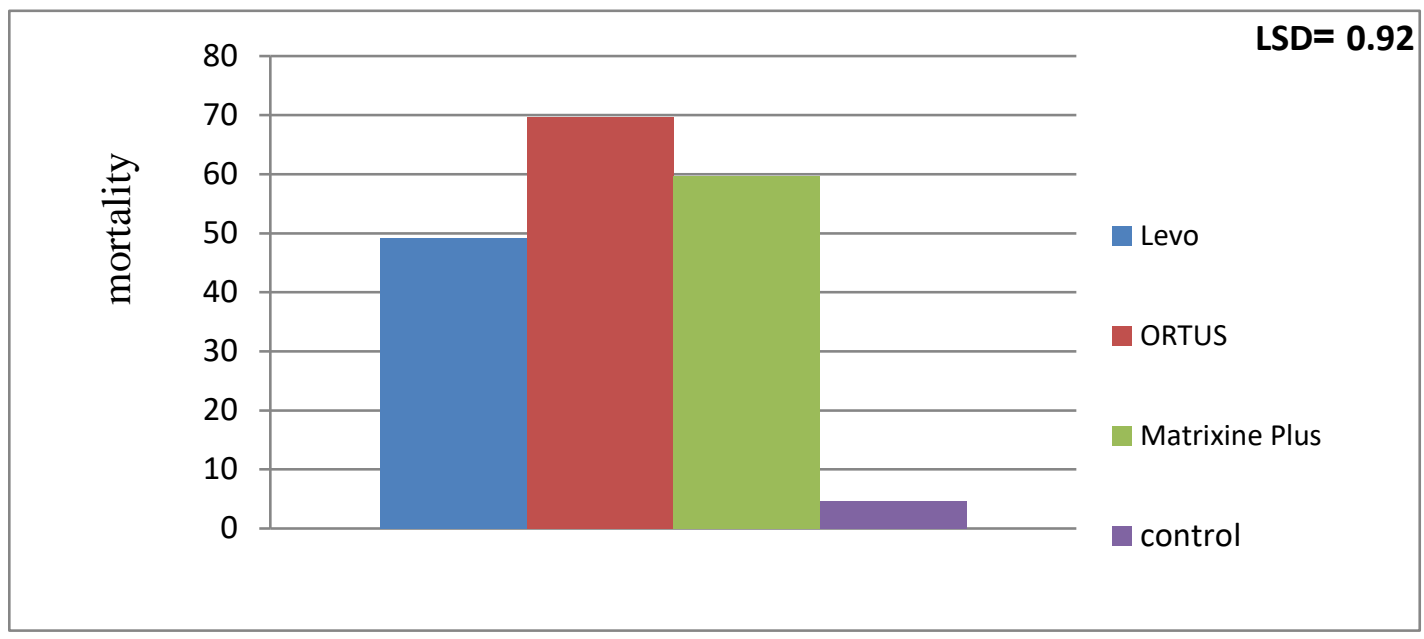

Fig. (2) Effect of pesticides on the mortality percentage of dust mites.

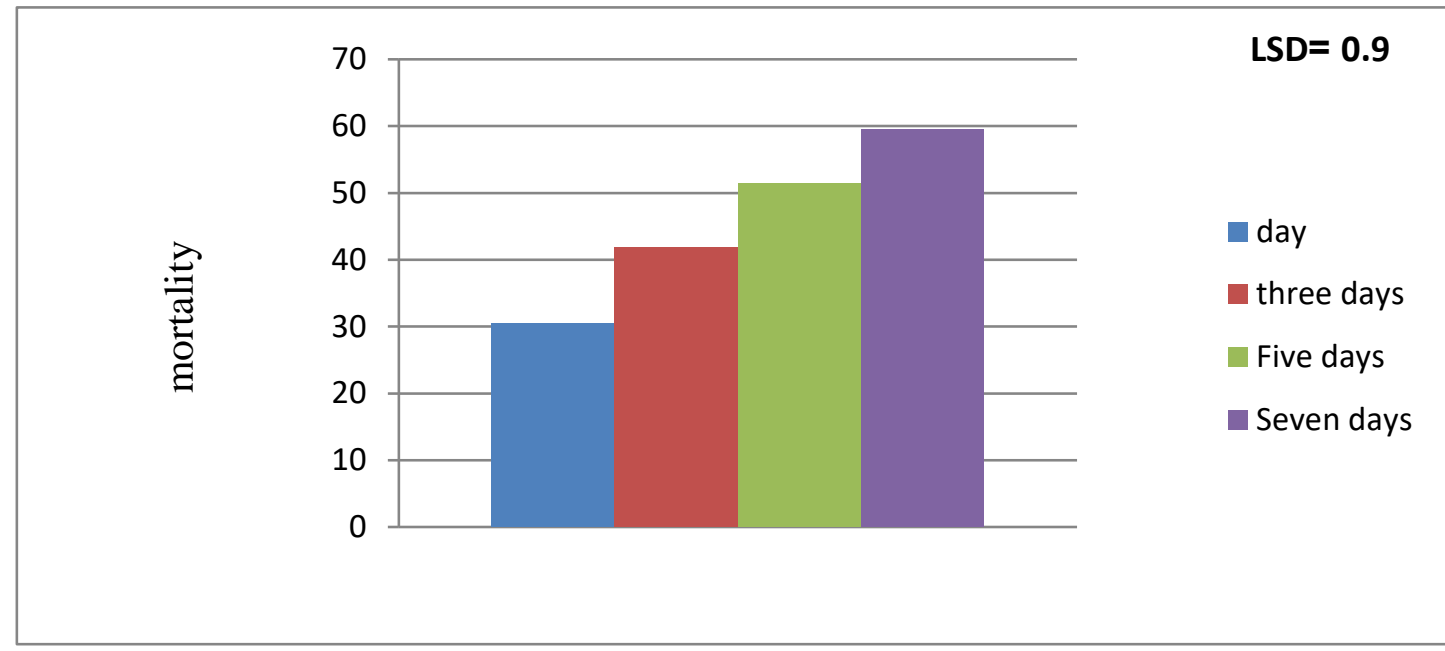

Fig. (3): Mortality percentage of dust mite after period (day) of treatment by pesticide

The results also showed that the mortality was increased gradually and was the highest after seven days post treatment, reaching $59.47 \%$ (Fig. 3).

The data presented in fig. (4) showed the interaction between the pesticides and spray intervals, the results revealed that the highest percentage of mortality of dust mite was achieved when Ortus pesticide was applied at first spray interval, it was $73.92 \%$, while the lowest percentage was appeared when the Levo pesticide was applied at third spray interval, it was $45.53 \%$.
The first spray (59.27\%) showed high efficacy than the rest, while the highest decreasing of mite density was at the first day after the third spray (27.97\%, fig. 5). According to the effect of the interaction between the pesticides and the spray application intervals, the Ortus was the most effective at seven days after the treatment $(89.77 \%)$ than the other applications, while the levo had the least effect at one day after the treatment recording the lowest rate of reduction of the mite density $(31.23 \%$, fig. $6)$. 
Ali \& Fhaid / Basrah J. Agric. Sci., 32 (2): 170-178, 2019

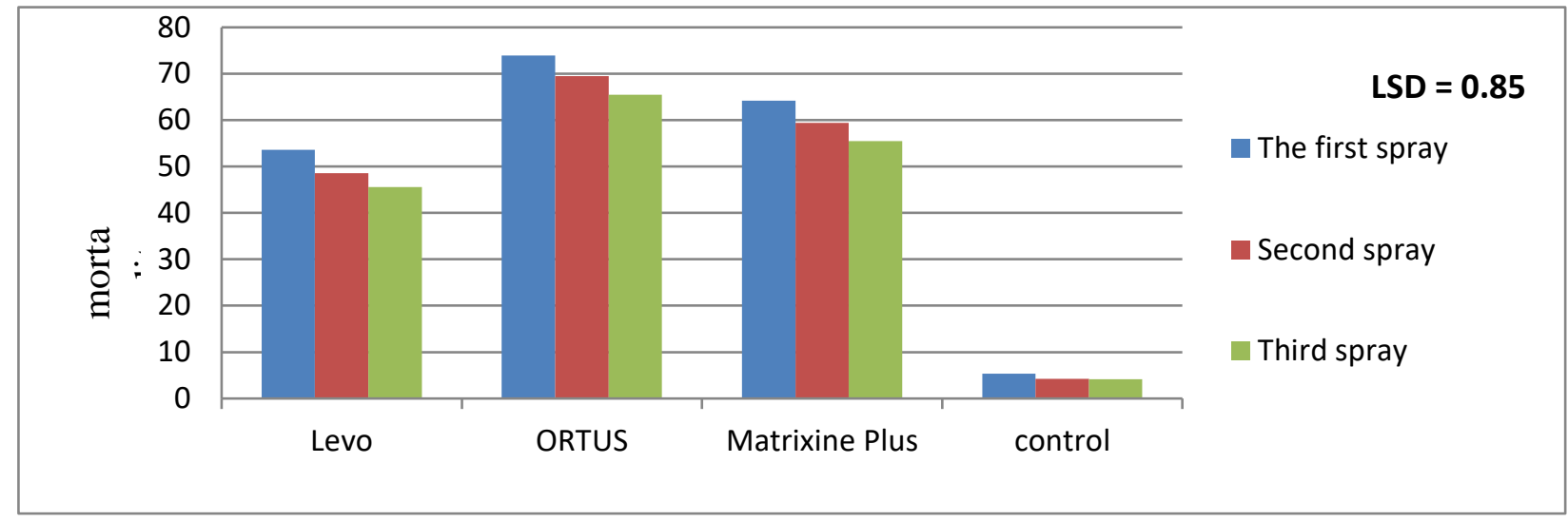

Fig. (4): The interaction between pesticides and spray intervals on mortality percentage of dust mite.

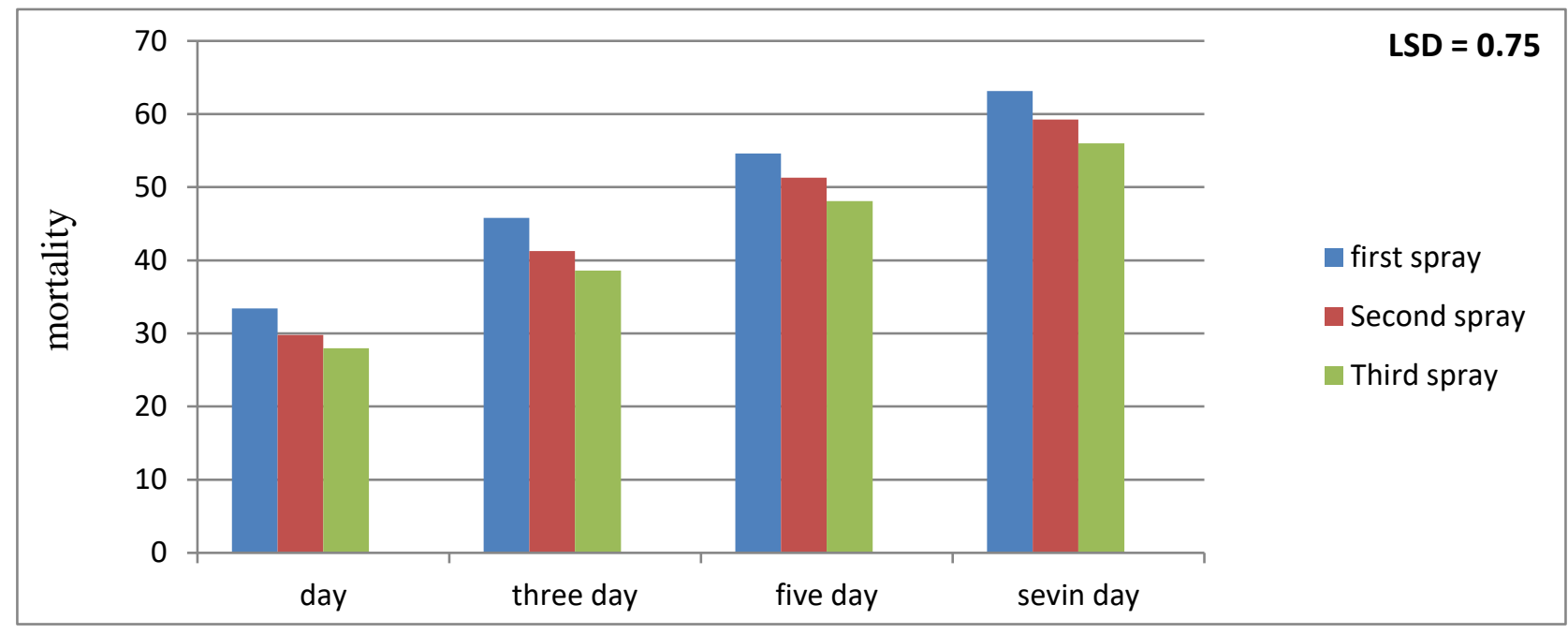

Fig. (5) the interaction between spray intervals and period after treatment (day) on the efficiency of pesticides of mortality percentage of dust mite.

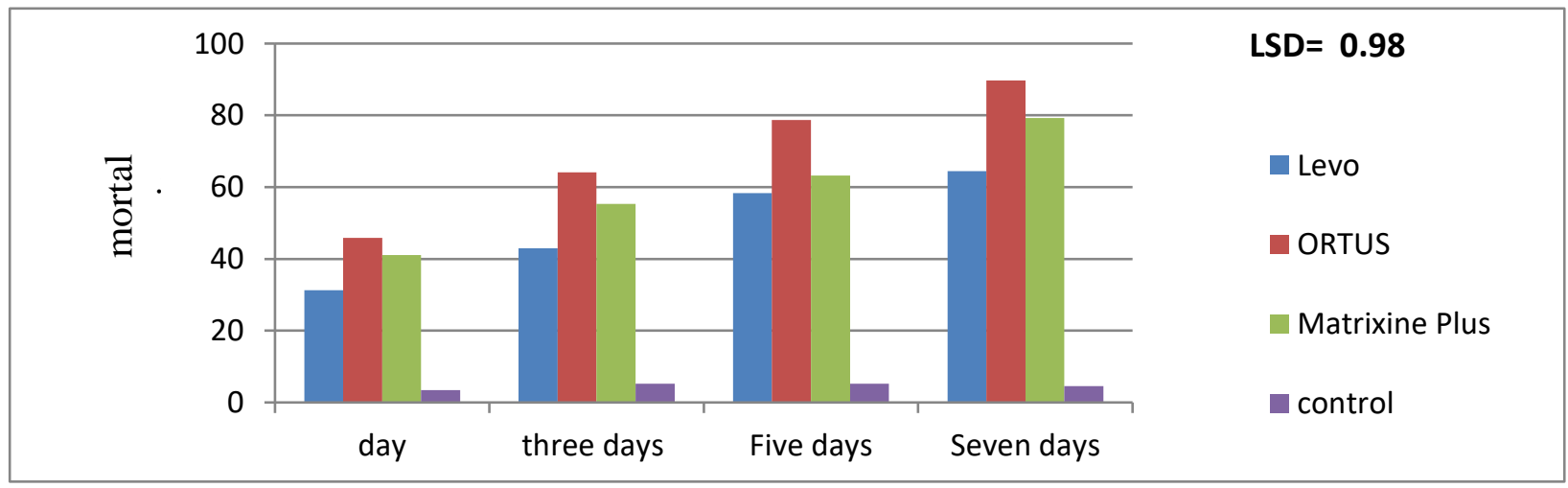

Fig. (6): Effect of the interaction of pesticidesand period after treatment (day) on the mortality percentage of dust mite.

Based on the results of table (2), the population density of dust mites on $\mathrm{cv}$. Halawi, Ortus at seven days after, significantly reduced the mite density by
93.24\% at the first spray compared to the rest treatments, while the levo at one day after the third spray gave the lowest rate $(27.71 \%)$. The results showed that Ortus gave a good activity 
Ali \& Fhaid / Basrah J. Agric. Sci., 32 (2): 170-178, 2019

at the first spray followed by Materxin Plus and Livo may be due to the spraying time, which was done coinciding with the reactivity time and initial dispersal of the mites dust $O$. afrasiaticus during the nutritional transmission from the leaflets to the fruits, while the efficacy of pesticides were decreased when the spray application was done later because the mites completed the silk spinning, which acts as a protective shield against the pesticide. This result was agreed with Brandenburg \& Kennedy (1987) who showed that the mite spinning web limited the efficacy of pesticides against the dust spider; Addesso et al. (2018) indicated that LE Noot katone was effective in the absence of the mite web causing mortality of $85 \%$, whereas the mortality was decreased to $12 \%$ in the presence of mite web.

Table (2) Effect of the spray application intervals of pesticides on the population density of date mites on cv. Halawi.

\begin{tabular}{|c|c|c|c|c|c|c|c|}
\hline \multirow{2}{*}{$\begin{array}{c}\text { Spray } \\
\text { intervals }\end{array}$} & \multirow[t]{2}{*}{ Pesticides } & \multicolumn{4}{|c|}{ Period after treatment (day) } & \multirow{2}{*}{$\begin{array}{c}\text { Average } \\
\text { of } \\
\text { pesticide }\end{array}$} & \multirow{2}{*}{$\begin{array}{c}\text { Average of spray } \\
\text { interval }\end{array}$} \\
\hline & & 1 & 3 & 5 & 7 & & \\
\hline \multirow[t]{5}{*}{ First } & Levo $2.4 \% \mathrm{SL}$ & 36.50 & 48.16 & 61.19 & 68.40 & 53.56 & 49.25 \\
\hline & ORTUS 5\% EC & 50.90 & 67.47 & 84.07 & 93.24 & 73.92 & \\
\hline & Matrixine Plus & 42.77 & 61.15 & 67.65 & 85.15 & 64.18 & \\
\hline & Control & 3.53 & 6.47 & 5.56 & 5.77 & 5.33 & \\
\hline & Average of period & 33.42 & 45.81 & 54.62 & 63.14 & & \\
\hline \multirow[t]{5}{*}{ Second } & Levo $2.4 \% \mathrm{SL}$ & 29.48 & 42.19 & 58.41 & 64.22 & 48.58 & \multirow{5}{*}{45.40} \\
\hline & ORTUS 5\% EC & 45.11 & 64.29 & 78.54 & 89.89 & 69.45 & \\
\hline & Matrixine Plus & 41.39 & 54.47 & 62.82 & 78.80 & 59.37 & \\
\hline & Control & 3.09 & 4.08 & 5.48 & 4.16 & 4.20 & \\
\hline & Average & 29.77 & 41.26 & 51.31 & 59.26 & & \\
\hline \multirow[t]{5}{*}{ Third } & Levo $2.4 \% \mathrm{SL}$ & 27.71 & 38.40 & 55.38 & 60.65 & 45.53 & \multirow{5}{*}{42.67} \\
\hline & ORTUS 5\% EC & 41.70 & 60.64 & 73.48 & 86.20 & 65.50 & \\
\hline & Matrixine Plus & 38.90 & 50.37 & 59.04 & 73.65 & 55.94 & \\
\hline & Control & 3.65 & 4.95 & 4.51 & 3.65 & 4.14 & \\
\hline & Average & 27.97 & 38.59 & 48.10 & 56.01 & & \\
\hline
\end{tabular}

The results were in agreement with what Gatarayiha (2009) stated that the destroying of the web is important for increasing the efficiency of the chemical control which increased the chances of exposure of all mite instars to the acaricides. The high efficacy of Ortus may be related to its chemical composition, containing a $5 \%$ fenpyroximate 
which has an inhibition activity of reductive enzyme NADH-CO $\mathrm{Q}$ in the mitochondria that decreases ATP in the mitochondria and affects the molting, metamorphosis, and development of mites (Motoba et al., 1992). The high effectiveness of insecticide levo may be related to the active ingredient Oxymatrine anti-feeding product which prevents the mite feeding (Marčić \& Međo 2014).

\section{Effect of the preventive spray on overwintering dust mites stages}

Results of table (3) showed low population density of dust mite in the untreated tress at the beginning of the mite activity after the overwintering period, the mean number of $O$. afrasiaticus was 8.6 mites. leaf let $^{-1}$ at the first sampling event 15 March, then population density showed an increasing trend in untreated plots starting from the second (24.53 mites. leaflet ${ }^{-1}$ ) at 15 April and the third sampling event (42.40 mites. leaflet ${ }^{-1)}$ at 15 May. However, the dormant spray (Sulfur, and Matrixine Oil) against overwintering stages reduced the mean number of the dust mites below the economic threshold. Sulfur applied at the concentration of (300 and 400) grams.tree ${ }^{-1}$ and Matrixine Oil (1.5 and 2) $\mathrm{ml}$. litre $^{-1}$ showed high efficacy in controlling of $O$. afrasiaticus and significantly decreased the mean number of the mites $(4.15,4.05,4.31$ and 3.96) mites, respectively, compared with the treatments of sulfur (200 grams. palm $\left.{ }^{-1}\right)$ and Matrixine Oil ( $1 \mathrm{ml}$. litre $\left.{ }^{-1}\right)(7.88$ and 7.53 mites) respectively. This results showed that dormant spray during winter season by using sulfur $(300,400)$ grams. palm $^{-1}$ and pesticide Matrixine Oil (1.5 and 2) ml. litre ${ }^{-1}$ would reduce effectively the infestation in the next season that reduced the amount of pesticide used to control the mites in the summer and reduced pollution of pesticide.

The results above agreed with the Awad et al. (1982) showed that dormant spray effectively reduced the population density of Red mites infesting fruit trees under the economic thresholds on apple and

Table (3): Effect pesticides application on overwintering dust mites stages.

\begin{tabular}{ccccc}
\hline treatment & The first time & The Second time & The Third time & Average treatment \\
\hline Sulfur 200 & 3.46 & 8.70 & 11.50 & $7.88 \mathrm{~b}$ \\
\hline Sulfur 300 & 0.46 & 4.86 & 7.13 & $4.15 \mathrm{c}$ \\
\hline Sulfur 400 & 0.36 & 4.06 & 7.73 & $4.05 \mathrm{c}$ \\
\hline Matrixine Oil 1 & 3.40 & 8.96 & 10.23 & $7.53 \mathrm{~b}$ \\
\hline Matrixine Oil 1.5 & 0.80 & 5.06 & 7.06 & $4.31 \mathrm{c}$ \\
\hline Matrixine Oil 2 & 0.63 & 4.23 & 7.03 & $3.96 \mathrm{c}$ \\
\hline Control & 8.63 & 24.53 & 42.40 & $25.18 \mathrm{a}$ \\
\hline Average & 2.53 & 8.63 & 13.30 & \\
& $\mathrm{C}$ & $\mathrm{B}$ & \\
\hline LSD (0.05) time $=0.58$ & LSD (0.05) & treatment $=$ & 0.89 \\
LSD (0.05) interference $=1.09$ & & \\
\end{tabular}


Ali \& Fhaid / Basrah J. Agric. Sci., 32 (2): 170-178, 2019

pomegranates trees by using Sandolin $46 \%$ during February, March, April, May, and June. The results also were in agreement with the Hamarassh et al. (2006) they proved that Winterol 96\% had high efficiency in dormant spray against overwintering pest. The results also were in agreement with the Kelderer et al. (2008) conducted in 2006 and 2007 evidenced a good and promising efficacy in reducing woolly apple aphid infestations of mineral oil based products. The early application of the treatment (just prior to bud burst) is important and ensures acceptable efficacy values. The results also were in agreement with the Epstein et al. (2000) who proved the importance of the preventative spray controls of aphids on plums and prunes: the leaf curls plum aphid (Brachycaudus helichrysi) and the mealy plum aphid (Hyalopterus pruni). The oil component of the application controls the European red mite (Panonychus ulmi) and the brown mite (Bryobia rubrioculus) on all of the orchard crops.

\section{Conclusion}

The results of this study proved that dormant spray was effective in the elimination of dust mite for the next season. Conducting chemical control shortly after pollination was effective in decreasing the population density of the pest.

\section{Acknowledgement}

I would like to thank Dr. Khairullah M. Awad, Date Palm Research Centre, University of Basrah, for his assistance in the statistical analysis.

\section{References:}

Addesso, K.M.; O’Neal, P.A.; Leahy, S.; Trostel, K., \& Behle, R.W. (2018). Evaluation of a lignin- encapsulated nootkatone formulation against Tetranychus urticae (Acari: Tetranychidae). Fla. Entomol., 101(3): 435-440.

Al-Dahwi, S.S.J. (2008). The influence of some integrated management practices for the control of the two spotted spider mite Tetranychus urticae Koch (Acari: Tetranychidae) on cotton. Ph. D. Thesis Coll. Agriculture. Univ. Baghdad: 186pp. (In Arabic).

Al-Dosary, N.H.; Al-Najim, I.A. \& Mahdi, H.A. (2013). The efficiency of Bahia and Ffendkm pesticides against lesser moth Batrachedra amydraula

(Lepedoptera: Cosmopterygidae) and dust mite Oligonychus afrasiaticus (M.) (Acari: Tetranychidae) during different periods and different parts of date palm trees. Basrah J. Agric. Sci., 26(2): 137-153. (In Arabic).

Al-Swuidy, T.M. (2003). Heat accumulation, fecundity schedules, and life tables structure of old word date mites (ghobar mites) Oligonychus afrasiaticus (McGregor) (Acari: Tetranychidae) M. Sc. Thesis Coll. Agriculture. Univ. Baghdad: 108pp. (In Arabic).

Awad, A.G.; Nidhal, H.R.; Shukriya, K. \& Mohammad, M. (1982). Control of red mites on deciduous trees by winter-spray of pesticides. Yearb Plant Protect. Res., 2(1): 169 175. (In Arabic).

Ba Angood, S.A. \& Basshaih, G.S. (2000). A study on the effect of date palm dust mite Oligonychus afrasiaticus (McGregor) (Acarin: Tetranychidae) on the physiochemical characters of three different date varieties in Wadi Hadhramout, Yemen. Arab J. Pl. Prot., 18(2): 82-85. (in Arabic). 
Ali \& Fhaid / Basrah J. Agric. Sci., 32 (2): 170-178, 2019

Brandenburg, R.L. \& Kennedy, G.G. (1987). Ecological and agricultural considerations in the management of two spotted spider mite Tetranychus urticae (Koch). Agric. Zool. Rev., 2: 185-236.

Epstein, L.; Bassein, S. \& Zalom, F.G. (2000). Almond and stone fruit growers reduce OP, increase pyrethroid use in dormant sprays. Calif. Agr., 54(6): 14-19.

Hamarassh, A.M.; Ali, A.A. \& Oueed, A.N. (2006). The effect of the growth regulator applaud and some chemical insecticides for the control of wax scale Ceroplastes rusci (L.) on fig trees in north of Iraq. Anbar J. Agric. Sci., 2(1): 169-175.

Gatarayiha, M.C. (2009 ). Biological control of the two-spotted spider mite, Tetranychus urticae (Koch) (Acari: Tetranychidae). Ph. D. Thesis Fac. Sci. Agric. Coll., Univ. KwaZulu-Natal: 218pp.

Kelderer, M.; Lardschneider, E. \& Casera, C. (2008). Winter treatments against the woolly apple aphid Eriosoma lanigerum products and timing of applications; proceedings to the $13^{\text {th }}$ Int. Conf. on cultivation technique and phytopathological problems in organic fruit growing. Weisberg, Germany. $18^{\text {th }}-20^{\text {th }}$ February 2008.

Marčić, D. \& Međo, I. (2014). Acaricidal activity and sublethal effects of an oxymatrine-based biopesticide on twospotted spider mite (Acari: Tetranychidae). Exp. Appl. Acarol., 64(3): 375-391.

Motoba, K.; Suzuki, T. \& Uchida, M. (1992). Effect of a newacaricide, fenpyroximate, on energy metabolism and mitochondrial morphology in adult female Tetranychus urticae (two-spotted spider mite). Pestic. Biochem. Physiol., 43(1): 3744.

Robinson, W.H. (1996). Urban Entomology. Chapman and Hall, London: 430pp. 